\title{
Tools of product policy as part of business marketing in the conditions of globalization
}

\author{
Veronika Olexova ${ }^{1, *}$, Darina Chlebikova ${ }^{1}$ \\ ${ }^{1}$ University of Zilina, Faculty of Operation and Economics of Transport and Communications, \\ Department of Economics, Univerzitna 1, 01026 Zilina, Slovakia
}

\begin{abstract}
.
Research background: Marketing is one of the key process for a successful business, because it deals with gaining and retaining customers, without whom the business would not make sense. Effective marketing benefits not only the company, but also the customer, because it helps to find the product that customer needs at the right time, in the right place and at an acceptable price. The product is one of the basic tools of the marketing mix and it is anything that can company offer in the market to meet the needs. In relation to the product and the overall product policy of the company, the company and its management must make a lot of decisions. Globalization has had a significant impact on the company's product policy as well as on the company's overall activities in recent years. It is a process as a result of which markets and production in different countries become increasingly interdependent due to the dynamics of trade in goods, services and the mobility of capital and technology.

Purpose of the article: The purpose of the paper is to point out the theoretical basis of product policy with emphasis on product policy tools. The paper also covers the impact of globalization on business marketing with an emphasis on product policy.

Methods: Method of analysis, synthesis, comparison, induction and deduction.

Findings \& Value added: Literature research in the field of product policy and new knowledge in the field of product policy with emphasis on the impact of globalization.
\end{abstract}

Keywords: globalization; marketing; marketing mix; product; product policy

JEL Classification: $F 6$; $M 1 ; M 3$

\footnotetext{
*Corresponding author: veronika.paurova@,fpedas.uniza.sk
} 


\section{Introduction}

The current economic and market environment is characterized by changes. These changes are reflected primarily in higher demands, expectations and changing customer needs. Companies are burdened with unpredictable customer requirements and are affected by global competition [1]. Customers are one of the most important entities for a company, because without them, the business itself would not make sense. This is the main reason why companies must constantly respond to customer requirements and needs. There is currently a lot of competition in the market, so companies must focus on achieving a competitive advantage that allows the company to gain many customers, and thereby strengthening its place in the market. Customer relationship management is an interactive process designed to achieve the optimal balance between business investment and customer satisfaction [2]. Succeeding in the market is not just a question of a quality product. There are currently many competing companies and their products are largely similar. Therefore, companies must take as many steps as possible to differentiate themselves from the competition. One of the tools that companies can achieve is marketing. Marketing is the process by which a business can meet the needs and requirements of individuals as well as entire customer groups. For a company to be successful in the market, it must have welldefined marketing goals that it wants to achieve. It must also have a correctly defined target group of customers and should adapt the individual tools of the marketing mix, marketing strategies [3] and marketing activities. Some experts still consider the marketing mix as one of the main elements of the overall marketing strategy and management. The most important element of the marketing mix is naturally the product itself [4]. A product is something a company produces and sells in the market. If the product is sold easily, it is not a big problem for the company. However, there are several products that are similar or even the same. It is here that competition arises between companies and companies must use product policy tools to differentiate themselves from the competition and reach customers. A good product policy is the foundation on which the right products are produced and sold successfully. Product policy consists of all measures that create a product program of a business entity to meet market requirements. The goal of the product policy is to produce the product based on the needs and wishes of the customer. Customers need a solution to their problems, which means that they need to create products that will be most advantageous for the customer in terms of their features [5]. One of the basic current development trends is the globalization of the world economy. It is therefore even more difficult for companies if they want to operate in an international or global market where competition operates. Globalization is a long-term development process of the world economy, within which there is a wide range of business in international markets as well as a new concept of the relationship between production, trade and the customer. One of the most actual effects on the current economy at the national as well as global level is the pandemic of the coronavirus COVID-19. The consequences of coronavirus COVID-19 on the global economy and markets are already clear. While some stores were closed for several weeks during a period of the COVID-19 pandemic, online stores operated essentially without restriction. However, in connection with this period, the shopping behaviour and shopping habits of customers also changed significantly. A significant part of their purchases has been transferred to the online environment. Businesses that have been able to adapt effectively to changes in consumer behaviour and changes in the overall market situation have benefited positively from the crisis. The theoretical part of the paper is focused on theoretical knowledge in the field of marketing and marketing mix with emphasis on the product tool and product policy. The practical part consists of a secondary analysis of data from the Statista, which is focused on the change in customers' shopping 
behaviour during the Covid-19 pandemic. The analysis results in an overview of product groups that have seen an increase in sales in the United Kingdom and the United States as a result of the COVID-19 pandemic.

\subsection{Marketing mix}

The marketing mix is a set of marketing tools that a company uses to achieve marketing goals in the target market. The company uses these tools to stimulate customer activities. With a good knowledge of customer needs and expectations, the company can use the individual elements of the marketing mix to guide customer behaviour according to the company's needs. It is a combination of marketing tools that the company combines into a certain unit to provoke the desired reaction in the target market and for the customer to buy the product. It contains all activities by which the company can influence the demand for its products. These are groups of marketing variables called 4Ps [6]. 4Ps of the marketing mix are defined as product, price, place and promotion [7]. Marketers use different combinations of the marketing mix in connection with the offer [8]. The marketing mix is a complex matter, where the resulting unit, if it is to be successful, must be harmoniously connected. The marketing mix includes tactical marketing decisions that relate to the product offered, its price, promotion and availability. The most important element of the marketing mix is the product itself [4], as the other elements of the marketing mix relate to the product being offered.

\subsection{Product}

A product is everything that a company offers on the market for purchase or consumption, which can satisfy the desires, wishes or needs of customers. It can be considered as a product not only any physical goods, but also various services, information, ideas, experiences and their combinations [4]. It is important for the company to choose the product or service that the potential customer is interested in. Every customer has certain ideas and expectations about the characteristics and quality of products and services that the company strives to meet [6]. With common products, it is possible to work with several characteristics that can differentiate yourself from the competition. These may include, but are not limited to, a variety of functional benefits, differences in materials used, differences in quality, performance, durability, reliability or repairability, differences in design, packaging, form, shape, size or quantity, differences in possible adaptation to individual needs and wishes, customers, differences in delivery speed, delivery conditions, warranties and installations as well as a range of additional services [4]. In terms of marketing, products are classified into 3 categories: product (individual product), product line and assortment. An individual product is any individual product designed for a customer that solves customer's problems. A product line is a group composed of individual products that are interrelated and perform similar functions. Assortment is a combination of relevant product lines and individual products that the company offers to customers. It is the overall market offer of the company, its entire range designed to satisfy the market [9]. From the point of view of the structure of the product, the basic characteristics of the product and its useful properties are distinguished, size, durability, all physical and chemical properties. Furthermore, a product- related service, such as payment and delivery conditions, service, warranty, etc. The last component of the company's structure is symbolic values, which include design and country of origin [10]. Over time, consumers became more demanding about the products on offer and expected more and more from the products. This is the reason why a five-level model was created, resp. five layers of product [10]. This model 
must be considered by companies when planning a marketing offer. The first level is the basic benefit. This is the main reason why the customer buys the product. The second level is the basic product. The third level is the expected product. This means a set of characteristics that customers in each product category expect. The fourth level is an improved product. It is a level at which it is possible to exceed customer expectations and thus differentiate yourself from the competition. The fifth level is a potential product. These are all possible improvements to the product. This is an area where marketers can look for inspiration for their innovations [4].

\subsection{Product policy}

Product policy is part of the marketing mix, which is focused on the analysis, planning, implementation and control of activities related to the product, which is a marketing tool. Product policy also concerns defining the type, volume and timing of products that a company offers for sale. Product policies are general rules established by management itself when making product decisions. A good product policy is the foundation on which the right products are produced and sold successfully. As part of product policy, companies deal with decisions about individual products. This decision-making focuses on product policy tools, such as: production program and range, quality, design, brand, packaging, business and technical services [5]. It is possible for companies to differentiate themselves from the competition and gain a competitive advantage by adding a certain functional benefit to the product. The design and aesthetics of the product, which are the basis of emotional differentiation, can also represent a significant competitive advantage. The product packaging is also closely related to the design. It must protect the goods, allow easy and safe opening and closing, provide a description of the product and be storable [4]. The production program is the overall structure of the products that the company produces and offers. Product quality is a set of product features that allow it to satisfy its intended and expected needs (perform its functions). Product quality includes its functionality, durability, safety, reliability, accuracy, requirements for operation and maintenance [6]. Perceived product quality is a key part of brand value. Perceived product quality is the most important prerequisite for customer satisfaction. This is closely related to customer loyalty. It is therefore necessary to pay close attention to the perceived quality of the product. If customers perceive product quality as insufficient, advertising or any other business communication tool will not help [4]. Businesses should seek information on the need for quality for further development [11]. Design is a design of a product that creates an aesthetic impression evoking an emotionally positive feeling in the customer's mind. Another important tool is the product brand. A product brand is a name, title, sign, symbol, or design, or a combination thereof. It concentrates the characteristics of the product under a unique designation. Its task is to identify the product of a seller and distinguish it from the products of the competition [5]. Brand building [12] affects many aspects that contribute to the success of products or services in the market [13]. An important tool of product policy is also the decision on product packaging. The product packaging should perform several functions, such as protection function, information function, recycling function, handling function and communication function. Packaging design is a key prerequisite for sales success, as much of the purchasing decision-making process takes place directly in stores. If the product has an interesting packaging design, it can attract the attention of buyers at the point of sale without the company having to invest heavily in marketing communication. The packaging design should be unique, attract the buyer's attention, sell the key benefits of the product and motivate the purchase. In the best case, the packaging design becomes part of the brand value, combined with a high degree of brand recognition [4]. Product policy tools are also business and technical services, which can be provided 
before, during or after the purchase. They include consulting, application and installation service, as well as technical service [5]. Under product policy instruments, businesses can improve products [14]. Related to this is, for example, sustainable production [15], product innovation, product modification, product line differentiation, product elimination as well as product diversification [9]. At present, companies should include elements of green marketing in their product policy [16]. For many consumers, ecology is becoming more important in product policy than other factors and tools [17]. The importance of individual product characteristics must always be evaluated from the perspective of the target customer. Companies should carefully test individual variants of their products. They should find out which characteristics of their products are most preferred by the target customers, whether they are different functional benefits or, for example, different variants of packaging design. At the same time, they should find out how much customers would be willing to pay for each product variant. There is talk of the so-called product research. With its help, companies can reach the optimal product variant (for a given target customer segment) and thus significantly increase the probability of product success in the market. All product characteristics must primarily correspond to the chosen marketing strategy, the target customer segment and the chosen brand positioning. In otherwise, the marketing strategy will not work. It is the product that manages the brand image [4].

\section{Methods}

In the context of COVID-19 pandemic period, among other things, the shopping behaviour and shopping habits of customers changed significantly. The aim of the practical part is to point out the change in the shopping behaviour of customers during the COVID-19 pandemic in the period May 2020. This part contains secondary data published by the research department of Statista. The Table 1 shows the products and services for which people in the United Kingdom and the United States have spent more money than usual due to the COVID-19 pandemic [18].

Table 1. Change in customers' shopping behaviour during the COVID-19 pandemic

\begin{tabular}{|l|c|c|}
\hline \multicolumn{1}{|c|}{ Products and services } & $\begin{array}{c}\text { United } \\
\text { Kingdom }\end{array}$ & $\begin{array}{c}\text { United } \\
\text { States }\end{array}$ \\
\hline Health and hygiene (e.g. medicine, hand sanitizer) & $36 \%$ & $43 \%$ \\
\hline Household cleaning products & $30 \%$ & $40 \%$ \\
\hline Food and drinks (e.g. shopping, takeaways, delivery) & $32 \%$ & $31 \%$ \\
\hline Home entertainment (e.g. video, games, books) & $21 \%$ & $26 \%$ \\
\hline Hobbies & $16 \%$ & $19 \%$ \\
\hline Housing, energy, maintenance (e.g. electricity, waste disposal, DIY) & $25 \%$ & $17 \%$ \\
\hline Consumer electronics, household appliances, furniture & $7 \%$ & $9 \%$ \\
\hline Clothing & $5 \%$ & $7 \%$ \\
\hline Investments & $5 \%$ & $7 \%$ \\
\hline Going out (e.g. restaurants, cinemas, pubs / bars) & $1 \%$ & $4 \%$ \\
\hline
\end{tabular}

Source: own processing based on statista.com

Due to COVID-19 pandemic, health and hygiene products, such as medicines and hand disinfectants, have reached the top of the consumer shopping list. There was also a significant increase in the purchase of household cleaners. Another group is food and drinks. Because many people spent more time at home, the increase in the purchase of home entertainment products is related. 


\section{Results}

Table 1 provides an overview of product groups that have seen a significant increase in sales due to the COVID-19 coronary virus pandemic. The result of this secondary data can be used by companies to reassess their product policy. As many companies have suffered significant losses as a result of this pandemic and have had a negative impact on their business activities, they should try to adapt their offer and products on offer to the current situation. Related to this is the fact that it is essential for companies to focus on all the tools of the marketing mix in equal parts.

\section{Discussion}

Nowadays, companies are moving more and more on the world market and their opportunities are theoretically located all over the world. In the context of a company's product policy, the strategic decision-making of businesses in conditions of competition and market globalization requires, in particular, knowledge of markets, a focus on quality and innovation [19]. The human factor is also important, especially as regards service provision. In many cases, the quality of services is assessed precisely because of the skill and skill of the employee, which customers can properly appreciate [5]. In business marketing, it is important that every part of the marketing mix is used equally to create and sell a successful product [20]. Businesses should carefully consider what characteristics to choose for their product. They should ensure what characteristics their customers really appreciate and at what price. Additional functional characteristics, increasing performance, the use of better-quality materials, more beautiful design, or better accompanying (additional) services, all this increases the cost of the product in general. It therefore makes sense to consider adding new product characteristics only if the increased costs can be offset by higher sales. It is also possible to consider removing a certain product characteristic, if it can be expected that this reduction will not result in a more substantial decrease in sales. Companies should not strive at all costs for maximum technical and technological excellence, which is usually bought by high production costs, and thus the selling price. The key factor is the value that the customer gets by buying the product [4]. The goal of every business is successful and long-term survival in the market. One of the key factors and at the same time the competitive advantage of the company is to achieve customer satisfaction [21]. The limitation of the survey is mainly the fact that it is secondary data just from the countries of Great Britain and the United States.

\section{Conclusion}

Given the current situation and changes in the global economy and the economy, it is essential that companies constantly monitor the ongoing conditions and changes in the market environment. It is therefore important to carry out surveys focusing on the products on offer as well as on consumer behaviour, for example in the context of the COVID-19 pandemic. Based on these surveys, companies can then implement their marketing activities with an emphasis on product policy and its tools, as well as other tools of the marketing mix.

This paper is an output of scientific project VEGA no. 1/0718/18: The impact of psychographic aspects of pricing on the marketing strategy of companies across products and markets. 


\section{References}

1. Hollowell, J.C., Kollar, B., Vrbka, J., Kovalova, E. (2019). Cognitive Decision-Making Algorithms for Sustainable Manufacturing Processes in Industry 4.0: Networked, Smart, and Responsive Devices. Economics, Management, and Financial Markets, 14(4), 9-15.

2. Krizanova, A., Gajanova, L., Nadanyiova, M. (2018). Design of a CRM Level and Performance Measurement. Model. Sustainability, 10(7), 2567.

3. Chankoson, T., Thabhiranrak, T. (2019). The moderating role of brand awareness between the relationship of emotional attachment, brand relationship and positive word of mouth. Polish Journal of Management Studies, 20(1), 129-138.

4. Karlicek, M. (2018). Zaklady marketingu. Praha: Grada.

5. Jakubikova, D. (2013). Strategicky marketing. Praha: Grada.

6. Smith, P. (2000). Moderni marketing. Praha: Computer Press.

7. Donndelinger, J., Fergusonl, S.M. (2017). Design for marketing mix: the past, present, and future of market-driven product design. In Proceedings of the ASME 2017 International Design Engineering Technical Conferences and Computers and Information in Engineering Conference (V02AT03A040). New York: AMER SOC MECHANICAL ENGINEERS

8. Dornyei, K.R. (2020). Limited edition packaging: objectives, implementations and related marketing mix decisions of a scarcity product tactic. Journal of Consumer Marketing, 37(6), 617-627.

9. Kral, P., Birnerova, E. (2013). Strategicky marketing. Zilina: EDIS.

10. Kita, J. (2017). Marketing. Bratislava: Wolters Kluwer.

11. Valaskova, M., Krizanova, A. (2008). The passenger satisfaction survey in the regional integrated public transport system. Promet - Traffic\&Transportation, 20(6), 401-404.

12. Zeman, Z., Bogdan, A. (2019). Marketing strategy and building brand value on the Hungarian market. Ekonomicko-manazerske spektrum, 13(2), 1-9.

13. Gavurova, B., Bacik, R., Fedorko, R., Nastisin, L. (2018). The Customer's Brand Experience in the Light of Selected Performance Indicators in the Social Media Environment. Journal of Competitiveness, 10(2), 72-84.

14. Deggans, J., Krulicky, T., Kovacova, M., Valaskova, K., Poliak, M. (2019). Cognitively Enhanced Products, Output Growth, and Labor Market Changes: Will Artificial Intelligence Replace Workers by Automating Their Jobs? Economics, Management, and Financial Markets, 14(1), 38-43.

15. Hayhoe, T., Podhorska, I., Siekelova, A., Stehel, V. (2019). Sustainable Manufacturing in Industry 4.0: Cross-Sector Networks of Multiple Supply Chains, Cyber-Physical Production Systems, and AI-driven Decision-Making. Journal of Self-Governance and Management Economics, 7(2), 31-36.

16. Majerova, J. (2015). Analysis of Slovak Consumer's Perception of the Green Marketing Activities. Procedia Economics and Finance, 26, 553-560.

17. Kliestikova, J., Krizanova, A., Corejova, T., Kral, P., Spuchlakova, E. (2018). Subsidies to Increase Remote Pollution? Science and Engineering Ethics, 24(2), 755767.

18. Statista - The Statistics Portal (2020, September 25). Products and services people spend more than usual on due to the COVID-19 / coronavirus pandemic in the United States, United Kingdom and Germany 2020. Statista. 
https://www.statista.com/statistics/1108088/products-and-services-people-spend-moreon-due-to-the-covid-19-pandemic/

19. Machkova, H. (2015). Mezinarodni marketing. Praha: Grada.

20. Marusic, T. (2019). Importance of marketing mix in successful positioning of products and services on the market. Ekonomska Misao i Praksa. Economic Thought and Practice, 28(1), 431-446.

21. Nadanyiova, M. (2014). The Customer Satisfaction with Services Railway Company Cargo Slovakia as a Factor of Competitiveness. In Proceedings of the 18th International Conference on Transport Means (pp.120-124). Kaunas: Kaunas University of Technology. 